\title{
MENYOAL HAMBATAN TUNA RUNGU DALAM MENINGKATKAN KETERAMPILAN TATARIAS DI PANTI SOSIAL BINA RUNGU WICARA MEOHAI
}

\author{
Arifuddin ${ }^{1}$, Syaifuddin S. Kasim ${ }^{2}$, Aryuni Salpiana Jabar ${ }^{3}$ \\ ${ }^{123}$ Universitas Halu Oleo \\ Email: arifuddin@gmail.com
}

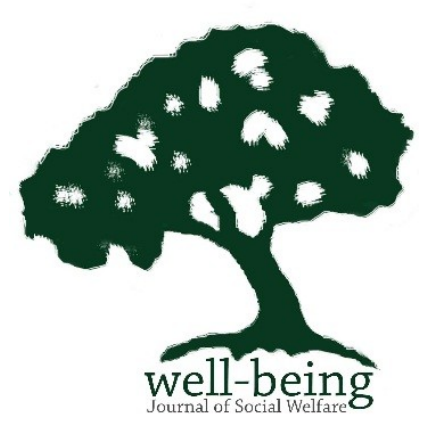

Anak tuna rungu wicara merupakan salah satu penyandang distabilitas tubuh yang ingin mendapat perhatian terpenuhi dengan adanya program-program dari pemerintah. Salah satunya yaitu melalui sistem pelayanan berbasis panti, dan salah satu lembaga yang melaksanakan program ini adalah Panti Sosial Bina Rungu Wicara Meohai (PSBRW) Kendari, yang dalam pelaksanaannya dilapangan tidak terlepas dari kontrol pihak panti baik itu individu, kelompok dan masyarakat yang mengalami distabilitas. Penelitian ini bertujuan untuk menggali lebih dalam lagi mengenai proses dan hambatan pelayanan yang ada di Panti Sosial Bina Rungu Wicara Meohai PSBRW Kendari, serta proses pelayanan Panti Sosial Bina Rungu Wicara Meohai Kendari. Metode penelitian yang digunakan dalam penelitian ini adalah metode kualitatif, sedangkan teknik pengumpulan data yang di gunakan adalah teknik wawancara, observasi, dan studi dokumentasi informan dalam penelitian ini adalah empat orang siswa-siswi, dua orang pekerja sosial. Sumber data yang di gunakan sumber data primer dan skunder, selanjutnya hasil penelitian ini dianalisis. Berdasarkan hasil penilitian menunjukan bahwa panti sosial bina rungu wicara membentuk pelakasanaan bimbingan keterampilan dan bimbingan materi lainnya baik individu maupun berkelompok namun demikian panti bina rungu wicara kekurangan tenaga ahli yang memiliki sertifikat SIBI, selain itu panti sosial bina rungu wicara terkendala oleh anggaran, sarana dan prasarana yang terbatas. Hal ini yang menjadi hambatan pelayanan bagi pihak panti.

Kata kunci: hambatan; tuna rungu; keterampilan; panti sosial

\section{PENDAHULUAN}

Terasingnya seseorang dapat disebabkan oleh karena cacat pada salah satu inderanya. Seseorang sejak kecil buta dan tuli misalnya, mengasingkan diri dengan sendirinya dari pengaruh-pengaruh kehidupan yang tersalur melalui kedua indera tersebut. Dari beberapa hasil penyelidikan, ternyata kepribadian orangorang tersebut mengalami banyak penderitaan sebagai akibat kehidupan terasing oleh karena cacat indera itu. Orang-orang cacat tersebut akan mengalami perasaan rendah diri oleh karena kemungkinan-kemungkinan untuk mengembangkan kepribadiannya seolaholah terhalang, dan bahkan tertutup sama sekali.

\section{Menurut Keputusan Menteri Sosial} RI Nomor 50/HUK/2004 tentang Standarisasi Panti, memberikan batasan bahwa sistem pelayanan kesejahteraan sosial diselenggarakan melalui sistem panti. Pelayanan sosial melalui sistem panti merupakan pelayanan alternatif terakhir, apabila fungsi dan peran keluarga/masyarakat tidak dapat dilaksanakan dengan baik untuk memenuhi kebutuhan anggotanya. Panti sosial merupakan lembaga pelayanan sosial yang memiliki tugas dan fungsi untuk meningkatkan kualitas sumber daya manusia dan memberdayakan penyandang masalah kesejahteraan sosial kearah kehidupan normatif secara fisik, mental dan sosial. Untuk itu Kementerian Sosial RI mendorong unit pelaksana teknis atau lembaga kesejahteraan sosial menciptakan 
lapangan pekerjaan agar penyandang disabilitas bisa hidup mandiri setelah keluar dari panti sosial karena penyandang disabilitas tidak mudah untuk mendapatkan pekerjaan sesuai dengan jenis distabilitasnya. Agar hidup mampu mandiri tersebut panti sosial diharapkan mendampingi dalam pengembangan keterampilan kerja dan usaha ekonomi produktif. Dengan adanya bimbingan ketrampilan anak tunarungu mereka dapat terlatih dan menghasilkan kretivitaskreativitas yang jauh lebih baik dari anak normal lainnya. Hadirnya seorang peksos dalam melakukan bimbingan harus dapat memberikan motivasi yang sesuai untuk mereka. Pada pelaksanaan bimbingan panti sosial bina rungu wicara diharapkan mampu meningkatkan keberfungsian sosial anak tuna rungu wicara sesuai standard sistem kepantian.

Panti sosial bina rungu wicara meohai kendari adalah salah satu panti yang memberikan pelayanan terhadap anak tuna rungu wicara yang ada di Sulawesi tenggara. Hal ini merupakan bentuk kepedulian pemerintah kepada anak-anak tuna rungu wicara menyiapkan suatu wadah untuk bisa mengolah diri dan mempersiapkan hidup dalam mengelolah masa depan mereka, dengan adanya panti sosial bina rungu wicara ini juga anakanak tuna rungu dapat belajar dengan baik dan tersruktur.Namun demikian dengan proses pelayanan ini panti bina rungu wicara meohai kendari sering mengalami hambatan-hambatan baik yang di sebabakan dari faktor internal maupun faktor eksternal.

\section{Basrowi,}

(2005.

Mengemukakan istilah tuna rungu sendiri berasal dari kata tuna yang berarti kurang dan rungu yang berarti pendengaran. Orang atau anak dikatakan tunarungu apabila ia tidak mampu mendengar atau kurang mampu mendengar bunyi atau suara. Berbagai batasan telah dikemukakan oleh para ahli tentang pengertian tunarungu atau dalam bahasa Inggris disebut Hearing Impairment yang meliputi Deaf (tuli) dan Hard of Hearing (kurang dengar). Dari pernyataan tersebut maka dapat diartikan bahwa tuna rungu adalah suatu istilah umum yang menunjukkan kesulitan mendengar, yang meliputi keseluruhan kesulitan mendengar dari yang ringan sampai yang berat, digolongkan ke dalam bagian tuli dan dengar. Orang tuli adalah seseorang yang mengalami kehilangan kemampuan mendengar sehingga menghambat proses informasi bahasa melalui pendengaran, baik itu memakai alat bantu ataupun tidak memakai Alat Bantu Mendengar (ABM).

Spicker dalam fahrudin (2012:49), seorang penulis Inggris, menyatakan bahwa pelayanan sosial meliputi jaminan sosial, perumahan, kesehatan, pekerja sosial, dan pendidikan (sebagai lima besar). Ini merupakan pelayanan sosial secara luas.

Berbagai pengertian mengenai pelayanan (service) banyaka dikemukakan oleh para ahli; diantaranya menurut American Marketing Association, seperti dikutif oleh Cowell dalam Sukmana (2015:105) menyatakan bahwa; “ pelayanan pada dasarnya adalah merupakan kegiatan atau manfaat yang ditawarkan oleh suatu pihak kepada pihak lain dan pada hakekatnya tidak berwujud serta tidak menghasilkan kepememilikan sesuatu, proses produksinya mungkin dan mungkin juga tidak dikaitkan dengan suatu produk fisik". Sementara menurut Christoper dalam Sukmana (2015:106), bahwa "service adalah produk yang tidak berwujud, berlangsung sebentar dan dirasakan atau dialami”.

Kamus Besar Bahasa Indonesia (1990 : 235), menjelaskan bahwa yang dimaksud dengan hambatan adalah hal yang menjadi penyebab atau karena hanya tujuan atau keinginan tidak dapat diwujudkan. Jadi, hambatan yang dimaksud dalam penelitian ini adalah halhal yang menyebabkan terhambatnya yang dihadapi panti bina rungu wicara dalam pelayanan siswa-siswi tuna rungu dan memperoleh pelayanan bimbingan dan pelayanan sosial. 
Berdasarkan temuan kurangnya pemahaman akan keadaan penerima mamfaat sehingga dapat mempengaruhi keterarahan program yang sesuai dengan kebutuhan penerima mamfaat. Pekerja sosial melakukan bimbingan belum berdasarkan hasil asesmen sehingga dalam pelaksanaan pelayanan ini tidak dapat di mamfaatkan oleh anak tuna rungu wicara untuk menggalang masa depannya. Temuan ini juga menggambarkan bahwa lemahnya dukungan sistem dari beberapa sumber di sebabkan pegawai panti/pekerja sosial yang belum memahami karakter siswa-siswi tuna rungu wicara. Sementara program bimbingan bagi penerima mamfaat masih terpaku pada pedoman pelaksanaan rehabilitasi lembaga yang hanya melakukan pendekatan kuratif semata bukan mengara pada pengembangan semua aspek baik ia sebagai individu maupun mahkluk sosial.

Hambatan yang di alami pekerja sosial lainnya adalah orang tua klien yang kurang terbuka tentang kondisi klien, karna kondisi klien yang sebenarnya tidak sesuai data yang diisikan dalam formulir sehingga rencana intervensi yang dibuat tidak sesuai dengan kenyataan klien dalam proses pelayanannya. Kepercayaan pihak luar pihak klien kurang karna keterampilan belum memenuhi standart yang di butuhkan sehingga penyaluran hanya terbatas pada pihak keluarga dan hanya sebagian kecil yang di terima dalam dunia kerja.

\section{METODE PENELITIAN}

Panti bina rungu wicara, yang menjadi objek penelitian adalah Panti bina rungu wicara "meohai" kendari di jalan Panjaitan No 22. Sebelum menentukan tempat penelitian, peneliti melakukan observasi melalui praktikum II. Pemilihan lokasi dilakukan secara sengaja (purposive). Panti bina rungu wicara dipilih karena telah melaksanakan berbagai pelayanan sosial kepada anak tuna rungu sejak tahun 1997/1998 dan belum ada penelitian mengenai hambatan pelayanan panti sosial binarungu wicara "meohai" terhadap peningkatan ketrampilan tatarias tersebut.

Dalam penelitian ini penulis menggunakan metode penilitian deskriptif kualitatif. Menurut Bogdan dan Taylor Dalam Thohirin, (2013) adalah prosedur penelitian yang menghasilkan data deskriptif berupa kata-kata tertulis atau lisan. Fokus adalah konsep yang mempunyai bermacam-macam nilai..Fokus penelitian ini adalah proses serta hambatan pelayanan panti sosial bina rungu wicara dalam meningkatkan ketrampilan tatarias yang di fokuskan objek kajian di jalan panjaitan No 22 kota kendari.

Subjek dalam penelitian disini ialah siswa-siswi tuna rungu wicara dan pekerja sosial, Penentuan informan dilakukan peneliti menggunakan teknik purposive sampling, dimana menurut Sugiono (2009) purposive sampling yaitu pengambilan sampel sumber data. Informan dalam penelitian ini sebanyak 6 orang yaitu 4 orang siswa-siswi yang terdiri dari siswa 2 orang dan siswi 2 orang, dan 2 orang pekerja sosiall serta kepala panti sebagai informan tambahan Dokumen yang di gunakan dalam penelitian ini adalah berupa catatancatatan resmi, foto, maupun yang relevan dengan masalah ini.

Observasi

merupakan pengamatan terhadap fenomena yang akan dikaji Menurut Koentjaraningrat,(2001) metode wawancara atau interview merupakan cara yang dipergunakan kalau seseorang mencoba mendapatkan keterangan. Peneliti menggunakan alat pengumpulan data yang berupa pedoman wawancara yaitu instrumen yang berbentuk pertanyaan yang ditujukan kepada siswa-siswi tuna rungu wicara.

$\begin{array}{ccr}\text { Menurut } & \text { Rachman } & (1996: 96), \\ \text { dokumentasi } & \text { merupakan }\end{array}$
mengumpulkan data melalui peninggalan tertulis, seperti arsip-arsip, buku-buku teori-teori, hukum-hukum yang berhubungan dengan masalah penelitian. Dalam penelitian ini, metode dokumentasi digunakan untuk memperoleh data seperti 
foto-foto siswa-siswi tuna rungu, dan aktivitasnya. Untuk menguji validitas penelitian kualitatif ini peneliti menggunakan teknik trianggulasi. Setelah keseluruhan informasi telah membentuk gambaran penelitian yang utuh, maka langkah selanjutnya adalah mengambil kesimpulan dari keseluruhan informasi tersebut.

\section{HASIL DAN PEMBAHASAN}

Permasalahan mendasar yang di hadapi penyandang cacat rungu wicara berkaitan dengan kondisinya adalah kemiskinan akan bahasa yang dapat mengakibatkan kehilangan ransangan yang paling vital bagi seseorang yaitu suara manusia yang membawa bahasa, yang dapat menggugah pikiran dan menempatkan kita dalam jajaran manusia intelektual. Selain itu, akibat mengalami gangguan pendengaran, PDRW mengalami hambatan emosional sosial, komukasi, pengetahuan dan kecerdasan serta mempersempit kesempatan pendidikan dan bekerja. Ketidak mampuan masyarakat untuk memahami dan mengerti keberadaan dan keterbatasan yang di miliki oleh PDRW karena secara visual PDRW diklasifikasikan sebagai invisible disability (kelainan tak nampak). Secara visual mereka terlihat orang normal namun setelah di ajak berkomunikasi atau berinteraksi dengan sesame manusia barulah nampak keterbatasannya. Ketersediaan tenaga teknis, pembina dan pelayanan yang sangat terbatas ditambah minimnya jumlah staf yakni hanya sebanyak 19 orang termasuk di dalamnya pekerja sosial fungsional merupakan salah satu permasalahan di dalam melaksanakan rehabilitas sosial bagi PDRW.

Panti Sosial merupakan unit pelaksana teknis di lingkungan Kementerian Sosial RI yang berada dibawah dan bertanggung jawab langsung kepada Direktur Jenderal Rehabilitasi Sosial, sehari-hari secara fungsional dibina oleh para Direktur terkait sesuai dengan bidang tugasnya (Peraturan Menteri Sosial Republik Indonesia Nomor 106 Tahun 2009 tentang Organisasi dan Tata
Kerja Panti Sosial di Lingkungan Departemen Sosial). Panti sosial bagi penyandang disabilitas merupakan pusat layanan yang berfungsi sebagai penyedia layanan dan fasilitas khusus bagi penyandang disabilitas.

\section{Proses Pelayanan}

Panti Sosial Bina Rungu Wicara mempunyai tugas memberikan bimbingan pelayanan dan rehabilitasi sosial yang bersifat kuratif, rehabilitatif, promotif dalam bentuk bimbingan pengetahuan dasar pendididkan, fisik, mental, sosial, pelatihan keterampilan, resosialisasi bimbingan lanjut bagi para penyandang cacat tubuh agar penyandang disabilitas tubuh mampu mandiri dan berperan aktif dalam kehidupan bermasyarakat. serta pengkajian dan penyiapan standar pelayanan, pemberian informasi dan rujukan (Permensos 106 tahun 2009).

Pemerintah telah meratifikasi konvensi tersebut melalui Undang-Undang Republik Indonesia Nomor 19 Tahun 2011 tentang pengesahan Convention On The Rights Of Persons With Disabilities (Konvensi Mengenai Hak-Hak Penyandang Disabilitas). Ratifikasi tersebut menunjukkan kesungguhan Negara Indonesia untuk menghormati, melindungi, memenuhi, dan memajukan hak- hak penyandang disabilitas, yang pada akhirnya diharapkan dapat memenuhi kesejahteraan para penyandang disabilitas. Sebagai tindak lanjut atas konvensi tersebut, telah diselenggarakan oleh Kementerian Sosial pada 19 panti sosial yaitu bagi penyandang disabilitas tuna netra, rungu wicara, cacat tubuh, tuna grahita, psikotik dan lara kronis. Pelayanan rehabilitasi sosial melalui panti ini bertujuan agar penyandang disabilitas bisa mandiri dan berpartisipasi di lingkungan sosialnya. Khusus untuk penyandang disabilitas tubuh. (Bandi Delphie, 2006).

\section{Hambatan Pelayanan}

Hambatan yang ada di Panti Sosial Bina Rungu Wicara (PSBRW) "Meohai" Kendari adalah berhubung 
dengan jumlah pekerja sosial yang tidak sebanding dengan jumlah siswa-siswi tuna rungu. Dengan jumlah pekerja sosial yang sangat minim tersebut sangat mempengaruhi proses pemberian pelayanan sosial kepada siswa-siswi tuna rungu. Hal ini karena jumlah pekerja sosial di Panti Sosial Bina Rungu Wicara (PSBRW) "Meohai" Kendari kurang lebih sebanyak 3 (tiga) orang serta profesi pekerja sosial pun merangkap jabatan belum lagi pekerja sosial diperhadapkan dengan jumlah lansia sebanyak 35 (tiga puluh lima) orang.

Hambatan pekerja sosial dalam pelaksanaan pelayanan bagi siswa-siswi tuna rungu adalah kondisi siswa-siswi yang terkadang sulit untuk di ajak bekomunikasi serta susah untuk diajak dalam kegiatan pelayanan bimbingan, sehingga sangat sulit seorang pekerja sosial apalagi pekerja sosial pemula dalam mengatasi permasalahan anak tuna rungu dan jumlah pekerja sosial yang tidak sebanding dengan jumlah siswasiswi yang ada di Panti Sosial Bina Rungu Wicara "Meohai" Kendari. Hambatan yang di alami pekerja sosial lainnya adalah orang tua klien yang kurang terbuka tentang kondisi klien, karna kondisi klien yang sebenarnya tidak sesuai data yang diisikan dalam formulir sehingga rencana intervensi yang dibuat tidak sesuai dengan kenyataan klien dalam proses pelayanannya. Pekerja sosial melakukan bimbingan belum berdasarkan hasil asesmen sehingga dalam pelaksanaan pelayanan ini tidak dapat di mamfaatkan tuna rungu wicara untuk menggalang masa depannya demikian juga kepercayaan pihak luar kepada pihak klien kurang karna keterampilan belum memenuhi standart yang di butuhkan sehingga penyaluran hanya terbatas pada pihak keluarga dan hanya sebagian kecil yang di terima dalam dunia kerja.

\section{KESIMPULAN}

Berdasarkan data-data yang di dapatkan selama proses penelitian maka di peroleh beberapa kesimpulan tentang
Hambatan Pelayanan Panti Sosial Bina Rungu Wicara Meohai (PSBRW) Kendari, apa saja yang menjadi hambatanhambatannya serta proses pelayanannya. Berdasarakan hasil penelitian Hambatan Pelayanan Panti Bina Rungu Wicara Meohai Dalam Meningkatkan Ketrampilan Tata Rias Siswa-Siswi Tuna Rungu.

Kesimpulan yang dapat diambil sebagai berikut:

1. Bentuk dan Pelaksanaan bimbingan dan metode bimbingan siswa-siswi tuna rungu

a) Bentuk dan pelaksanaan

- Bimbingan fisik dan mental ini dilaksankan dalam pemberian beberapa materi baik itu agama, budi pekerti, bahasa isyarat, SIBI atau olahraga.

- Bimbingan ketrampilan disini memiliki bagian dalam pelaksanaanya di antaranya tat arias, menjahit dan sablon.

b) Metode Bimbingan

- Dinamika kelomopok. Dinamika kelompok ini dilakukan setiap bimbingan dimana siswa-siswi dibagi dalam kelompok-kelompok dalam perkolompokan ini tidak membedakan yang satu dengan yang lain, baik siswa-siswi yang mempunyai IQ tinggi ataupun rendah semua di campur.

- Bahasa isyarat adalah salah satu bentuk komunikasi bagi siswa-siswi tuna rungu.

- Metode ceramah. Metode ceramah ini dilakukan dimana pekerja sosial 
memberikan materi-materi sesuai dengan bidangnya sementara siswa-siswi berinteraksi menambahkan dengan bahasa isyarat.

2. Hambatan panti sosial bina rungu wicara dan pekerja sosial

Adapun hambatan yang di alami oleh pekerja sosial ketika sedang melakukan perannya yaitu, kurangnya jumlah perja sosial yang ada dipanti tersebut, kurangnya anggaran dari pimpinan, kurangnya pekerja sosial yang berserifikat SIBI serta sarana dan prasarana yang kurang memadai serta pengorganisasian dan metode kerja yang tidak sejalan dan akurat dalam bekerja dan juga kemampuan pengetahuan yang kurang pada pekerja sosial serta pegawai yang lainnya. Hal-hal ini yang menjadi hambatan panti sosial bina rungu wicara dan pekerja sosial dalam melakukan tugasnya.

\section{SARAN}

Bedasarkan temuan dilapangan dan hasil analisa mengenai hambatan pelayanan panti dalam meningkatkan ketrampilan tata rias siswa-siswi tuna rungu di PSBRW terdapat beberapa hal yang harus di perbaiki untuk memajukan kemampuan dan kreatifitas siswa-siswi di masa yang akan datang dan untuk meningkatakan jumlah pekerja sosial yang ada di PSBRW serta sarana dan prasarananya harus di tamabah. Semoga saran yang di berikan dapat bermamfaat.

\section{DAFTAR PUSTAKA}

Basrowi, 2005. Penyebab Tuli Pada Anak Luar Biasa. Dalam Majalah Ayah Bunda.

Prastowo, 2011. Metodologi Penelitian

Sosial Format - Format Kuantitatif

Dan

Kualitatif, Airlangga University Press, Surabaya.

Rachman, 1997. Metode penelitian sosial. Bandung
Koentjaraningrat, 2001. Pendekatan Kualitatif Dalam Pengertian Psikologis. Jakarta.

Moleong, J.Lexy. 2005. Metode Penelitian Kulitatif. PT Remaja Rosdakarya:Bandung.

Arikunto, 1997. Dasar- Dasar Evaluasi Pendidikan, Jakarta, Bina Aksara.

Delphie, Bandi. 2006. Pembelajaran Anak Berkebutuhan Khusus, Bandung, Refikha Aditama

Fathoni, 2004. Metode Penelitian. Jakarta: Gahlia Indonesia

Fahrudi, adi. 2012. Pengantar kesejahteraan sosial. Bandung: PT Refika Aditama

Sukmana, 2015. Bahan Ajar Pendidikan Anak Berkebutuhan Khusus.Pontianak.

Depdikbud, Kamus Besar Bahasa Indonesia, Jakarta, Balai Pustaka

Dwidjosumarto, A. 1994. Ortopedagogik Anak Tunarungu. Proyek Pendidikan

Tenaga AKademik, Direktorat Jenderal Pendidikan Tinggi

Hernawati, 1996. Penguasaan Bahasa Anak Tuna Rungu. Proyek Tenaga Akademik.

Yayasan Santi Rama.

Koentjaraningrat, 2001. Pendekatan Kualitatif Dalam Pengertian Psikologis. Jakarta.

Kurniawan, 2005. Teori dan Praktek Pelayanan Sosial melalui panti asuhan. Jakarta

Muhidin Syarif, 1997. Pendidikan luar biasa umum. Proyek pendidikan Tenaga Akademik, Direktorat Jendral Pendidikan Tinggi

Nuryanti, 2006. Pendidikan Luar Biasa Introduction to Special Education. Bandung: PT Remaja Rosda Karya

Nurdi Fadhil M. 1990. Perkembangan Peserta Didik. Yogyakarta: UNY Press.

Sakyidah Fanani , 2009. Pendidikan Institut Keguruan dan Ilmu Pendidikan. Yogyakarta.

Edja Sadjaah dan Darjo Sukarja, 2003. Psikologi Perkembangan Suatu Pendekatan 
Sepanjang Rentang Kehidupan, Jakarta, Erlangga.

Suharto, Edi. 2005. Membangun Masyarakat Memberdayakan Rakyat. Bandung:Refika Aditama.

Situmorang Chazali, 2013. Perkembangan Dewasa Muda. Jakarta: Grafindo

Yuli Satyani. 2005. Universitas Negeri Yogyakarta

Undang-undang nomor 13 tahun 1998 pasal 3 tentang kesejahteraan sosial

Undang-Undang Nomor 23 Tahun 2002 Tantang Perlindungan Anak

Undang-Undang Nomor 11 Tahun 2009

Tentang Kesejahtraan Sosil 